УДК 636.39.085:631.828:637.12.043

(C) 2012

Рижкова Т. М., кандидат технічних наук,

Васильєв В. С., кандидат біологічних наук,

Гончарова I. І., кандидат сільськогосподарських наук

Харківська державна зооветеринарна академія

Лівощенко І. М., ветеринарний лікар, пошукач

Харківська регіональна державна лабораторія ветеринарної медицини

\title{
ДИСПЕРСІЯ МОЛОЧНОГО ЖИРУ ПІД ВПЛИВОМ ЙОДОВМІСНИХ ДОБАВОК, ЩО ВВОДИЛИСЯ ДО РАЦІОНУ КІЗ
}

\author{
Рецензент - доктор сільськогосподарських наук, професор Ю. Д. Рубан
}

\begin{abstract}
Викладено результати впливу водовмісних підкормок на технологічні властивості козиного молока, зокрема, на дисперсність його жирових кульок.

Встановлено, щзо жирова компонента проб молока, отриманих від тварин, до раціону яких додатково вводили добавки «Еламін» та калію йодид, мають більш високу дисперсність жирових кульок, щзо впливає на підвищення його засвоюваності організмом людини. Також молоко молоко від кіз, до раціону згодовування яких вводили дві вищевказані йодовмісні підкормки, є більш технологічним, аніж козине молоко, отримане від кіз звичайного раціону згодовування, так як не потребує проведення проиесу його гомогенізаиії.
\end{abstract}

Ключові слова: козине молоко, молочний жир, йодовмісні добавки, дисперсність жирових кульок, жирова компонента, йододефіцит.

Постановка проблеми. Нині повноцінність продуктів харчування визначається їхньою енергетичною цінністю, збалансованістю раціону харчування щодо вмісту білків, жирів і вуглеводів, а також забезпеченістю макро- і мікроелементами.

Одним із найбільш дефіцитних мікроелементів у продуктах харчування $є$ йод. Тому суттєве значення в галузі створення продуктів функціонального призначення має виробництво молочної сировини з підвищеним умістом йоду та його переробка на питне молоко, ферментовані молочні продукти (сичужний сир, сир кисломолочний, кефір та ін.).

Аналіз основних досліджень i публікацій, у яких започатковано розв'язання проблеми. За оцінкою ВООЗ, понад 2 мільярди жителів Землі мають недолік йоду в харчуванні, що призводить до розвитку йоддефіцитних захворювань. Глобальне поширення зобу в загальній світовій популяції становить 15,8 \% [10].

Усі патологічні стани, які розвиваються внаслідок йодного дефіциту і яким можна запобігти при нормалізації споживання йоду, визначаються як йоддефіцитні захворювання.

Йоддефіцитні захворювання, за даними ВООЗ, $\epsilon$ найпоширенішою неінфекційною патологією в світі: 1570 млн чоловік (30\% населення світу) мають ризик їх розвитку, в тому числі, 500 млн людей проживають у регіонах з важким дефіцитом йоду і високою поширеністю ендемічного зобу; 43 мільйони страждають розумовою відсталістю, що розвинулася в результаті йодної недостатності. За ініціативи ВООЗ, у ХХ столітті проблема дефіциту йоду майже у $40 \%$ населення Землі визнана ООН глобальною [11].

До одного 3 джерел, що містить органічний йод, який може бути ефективно використаний для збагачення ним продуктів харчування, відносяться морські водорості. Вони містять альгінову кислоту, макро- і мікроелементи, клітковину, вітаміни й інші біологічно активні речовини, які у вигляді сухого концентрату з бурої морської водорості виду Laminaria виготовляє і реалізує населенню України Київський ВАТ «Завод молочної кислоти» [4]. Добавка може бути використана і в якості підгодівлі для сільськогосподарських тварин.

У світовій практиці простежується тенденція заміни коров'ячого молока на козяче, яке все частіше використовують у виробництві ферментованих молочних продуктів (сичужних сирів і сиру), продуктів дитячого та дієтичного харчування (кефіру) [9].

Однією з особливостей козячого молока $€$ те, що його жирові кульки мають, порівняно 3 аналогічним показником коров'ячого молока, більш дрібнодисперсну структуру. Це сприяє кращому його засвоєнню організмом людини, у порівнянні $з$ коров'ячим. До того ж для засвоєння такого молока енергетичні витрати менші, що позитивно позначається на здоров'ї споживачів молочних продуктів із козячого молока $[5,6]$. 
Останнім часом, у зв'язку зі зростаючим інтересом до козиного молока як сировини для молокопереробної промисловості, виникає необхідність у підборі оптимальних режимів його переробки.

Зустрічаються роботи, пов'язані з проведенням оптимізації режимів його теплової обробки (пастеризації, охолодження, нагрівання, згортання) у виробництві сичужних сирів і сиру [7], але питання про необхідність проведення процесу гомогенізації нормалізованої суміші козячого молока у процесі виробництва кисломолочних продуктів або про можливість його виключення 3 технологічного ланцюга виробництва досі залишається не вирішеним.

Відомо, що гомогенізація досить широко використовується в молочній промисловості у процесі виробництва цілого спектру продуктів, для яких розшарування жирової фракції молока має негативні наслідки, в тому числі й для питних і кисломолочних видів молочних продуктів.

Мета гомогенізації - подрібнення жирових кульок молока до розмірів, які забезпечують необхідну стабільність жирової фази молока. Для досягнення вказаної мети необхідно, щоб середній діаметр жирових кульок не перевищував 2 мкм. Ефективність гомогенізації вважається задовільною, якщо частка жирових кульок діаметром менше 2 мкм перевищує 80-85\% [8].

Отже, виключення процесу гомогенізації козиного молока дасть змогу підвищити ефективність його використання у виробничих умовах молокопереробних підприємств країни. Відомо, що поживні, в тому числі, мінеральні речовини, потрапляють у організм тварин і переходять у молоко переважно 3 кормів і мінеральних добавок [2].У проведених нами дослідах, у раціон дійних кіз додатково вводили йодовмісні підкормки, дію яких відстежували за зміною дисперсності жирових кульок у контрольних і дослідних пробах молока.

Слід зазначити, що більшість наукових праць присвячено вивченню питань поліпшення сиропридатності молока та збільшення удою під впливом йодовмісних добавок, зокрема, під впливом йодиду калію [3]. При цьому відомості про зміну дисперсності жирової фракції козиного молока під впливом йодовмісних добавок у процесі переробки козячого молока на кисломолочні продукти носять фрагментарний характер.

Метою досліджень $є$ визначення впливу водовмісних підкормок на технологічні властивості козиного молока, зокрема, на дисперсність його жирових кульок.
Методи проведення досліджень: проведення порівняльної характеристики жирові компоненти козячого молока, отриманого від кіз, у раціон яких вводилися дві йодовмісні підкормки: «Еламін» і калію йодид, в оптимальних для життєдіяльності кіз нормах, а також без їх використання.

Для цього у фермерському господарстві «Шеврет», розташованому в Мостиському районі Львівської області, був поставлений науковопрактичний дослід, яким передбачалося введення до основного раціону дослідних груп кіз двох йодовмісних добавок.

Перша група кіз - контрольна № 1 . Друга i третя групи тварин - дослідні, до основного раціону згодовування яких додатково вводили калій йодид із розрахунку 0,9 мг і «Еламін» у кількості 1,26 г на одну голову на добу, відповідно.

Методика вимірювання розмірів кульок молочного жиру в пробах молока проводилася за допомогою інтерференційного мікроскопа, який, на відміну від звичайного, дає змогу з виразною контрастністю спостерігати крапельки молочного жиру в молоці і вимірювати їх розміри, суху масу й інші показники.

Досліди супроводжувалися фотографуванням жирових кульок у контрольній пробі молока № $1 \mathrm{i}$ двох дослідних пробах № 2 та № 3 від кіз, які отримували йодовмісні підкормки. Зображення молочного жиру представлені у диференціальному інтерференційному контрасті за збільшення 1000. Проводили вимірювання діаметрів не менше ніж у 1000 жирових кульок і будували за цими даними гістограми або полігон розподілу розмірів із кроком 0,4-0,5 мкм (рис. 1a-3a) за методикою, розробленою В. С. Васильєвим, 1978 [1].

Результати досліджень. Дослідження показали, що у контрольних пробах молока кіз типового раціону згодовування сума жирових кульок діаметром від 2,5 мкм до 5 мкм становить $54,6 \%$, а сума жирових кульок діаметром від 0,5 мкм до 2,0 мкм $-45,4 \%$.

У дослідних пробах молока № 2, отриманих від кіз, до основного раціону згодовування яких додатково вводили йодид калію, сума жирових кульок діаметром від 2,5 мкм до 5 мкм становить $84,7 \%$; сума жирових кульок діаметром від 0,5 мкм до 2,0 мкм - 15,3\%.

У дослідних пробах молока № 3, отриманих від кіз, до основного раціону згодовування яких додатково вводили «Еламін», сума жирових кульок діаметром від 2,5 мкм до 5 мкм становить $78,5 \%$, а сума жирових кульок діаметром від 0,5 мкм до 2,0 мкм - 21,5 \% (див. табл.). 
СІЛЬСЬКЕ ГОСПОДАРСТВО. ТВАРИННИЦТВО

Розмір жирових кульок проб молока, отриманих від контрольної та дослідних груп кіз

\begin{tabular}{|c|c|c|c|}
\hline $\begin{array}{c}\text { Діаметр жи- } \\
\text { рових кульок, } \\
\text { мкм }\end{array}$ & Кількість і розміри жирових кульок у пробах молока та їхнє співвідношення, \% \\
\cline { 2 - 4 } & контрольна група №1 & $\begin{array}{c}\text { дослідна група № } 2 \\
\text { (молоко від кіз, } \\
\text { які отримували йодид калію) }\end{array}$ & $\begin{array}{c}\text { дослідна група № } 3 \\
\text { (молоко від кіз, які } \\
\text { отримували «Еламін») }\end{array}$ \\
\hline 1 & 2 & 3 & 4 \\
\hline 0,5 & $48 \pm 0,76(4,8 \%)$ & $175 \pm 0,882(17,5 \%)$ & $71 \pm 0,715(7,1 \%)$ \\
\hline 1 & $130 \pm 0,65(13,0 \%)$ & $249 \pm 0,83(24,9 \%)$ & $241 \pm 0,70(24,1 \%)$ \\
\hline 1,5 & $161 \pm 0,84(16,1 \%)$ & $240 \pm 0,58(24,0 \%)$ & $290 \pm 0,56(29,0 \%)$ \\
\hline 2 & $207 \pm 0,96(20,7 \%)$ & $183 \pm 0,82(18,3 \%)$ & $183 \pm 0,73(18,3 \%)$ \\
\hline 2,5 & $189 \pm 0,94(18,9 \%)$ & $98 \pm 0,76(9,8 \%)$ & $107 \pm 0,80(10,7 \%)$ \\
\hline 3 & $141 \pm 0,83(14,1 \%)$ & $41 \pm 0,715(4,1 \%)$ & $69 \pm 0,80(6,9 \%)$ \\
\hline 3,5 & $93 \pm 0,7(9,3 \%)$ & $12 \pm 0,83(1,2 \%)$ & $27 \pm 0,66(2,7 \%)$ \\
\hline 4 & $21 \pm 0,70(2,1 \%)$ & $2 \pm 0,42(0,2 \%)$ & $12 \pm 0,60(1,2 \%)$ \\
\hline 4,5 & $8 \pm 0,68(0,8 \%)$ & & - \\
\hline 5 & $2 \pm 0,73(0,2 \%)$ & & - \\
\hline
\end{tabular}

На рис. № 1 та рис. 1а представлено зображення крапель молочного жиру контрольної проби молока, отриманого від кіз типового раціону згодовування.

На рис. № 2 та рис. 2а представлено зображення крапель молочного жиру в дослідних пробах молока № 2, отриманих від кіз, яким додатково до раціону згодовували йодид калію.

На рисунках №3 та 3а представлено зображення жирових кульок у дослідних пробах молока № 3, отриманих від кіз, яким додатково до раціону вводили « Еламін».

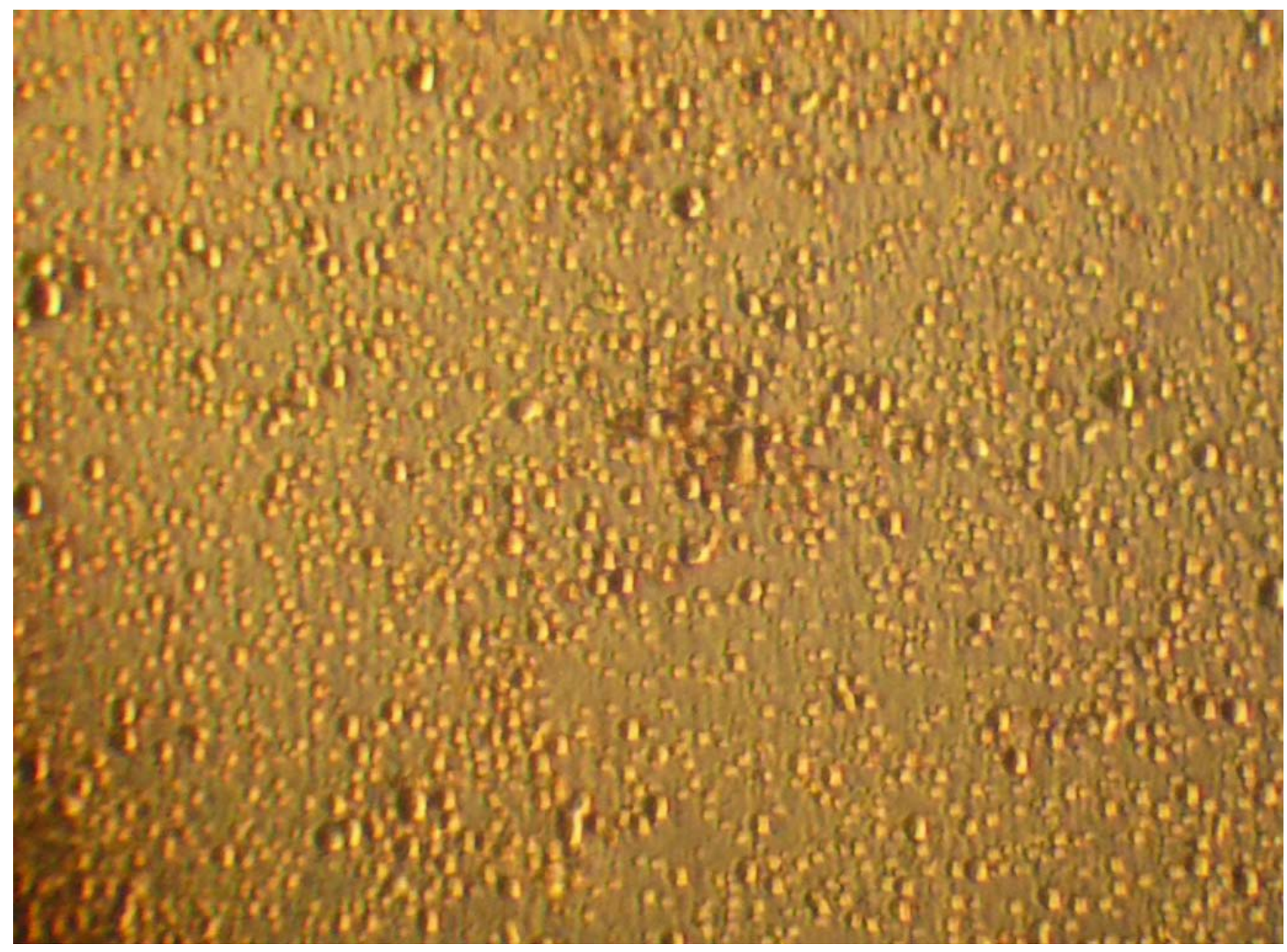

Рис. 1. Жирові кульки у контрольній пробі молока № 1 (без підгодівлі водовмісними підкормками) 


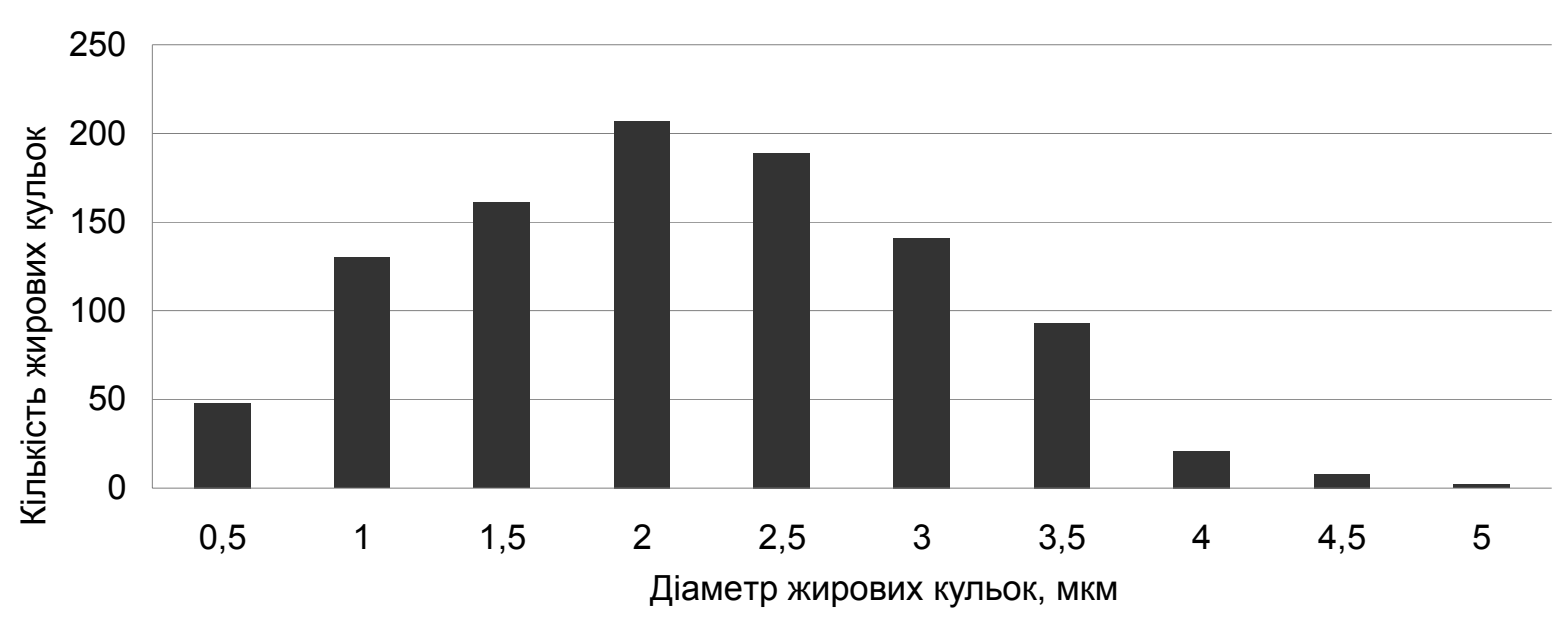

Рис. 1а. Дисперсія молочного жжиру проб молока № 1 від кіз типового раціону згодовування

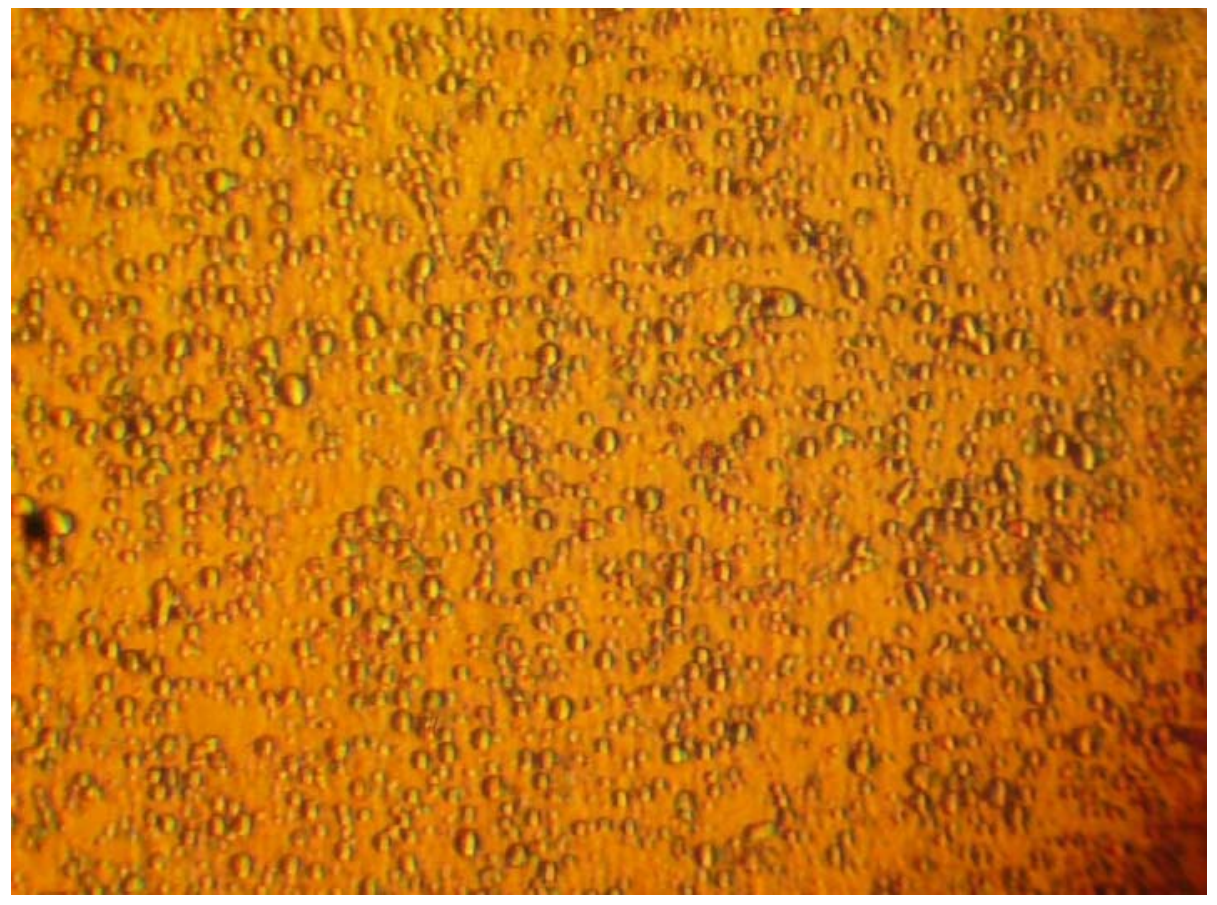

Рис. 2. Жирові кульки молочного жиру в дослідних пробах молока №2 від кіз, яким додатково згодовували КЈ

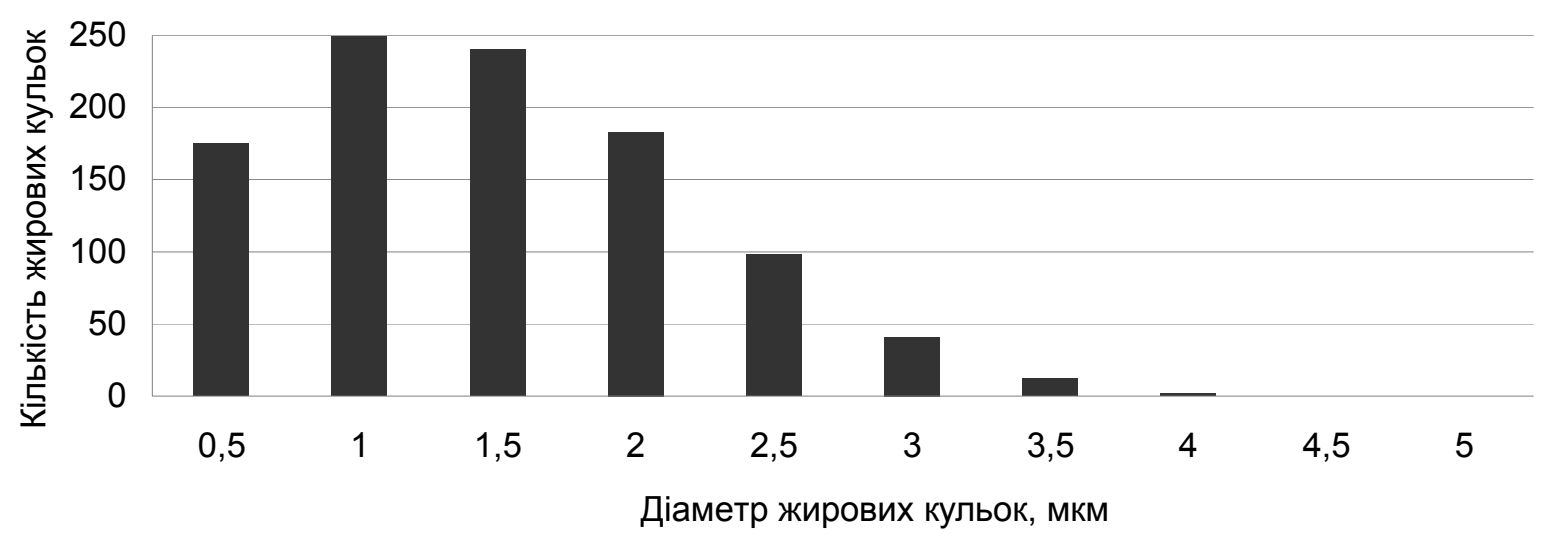

Рис. 2а. Розподіл розмірів жирових кульок у дослідній пробі молока №2 (КJ) 


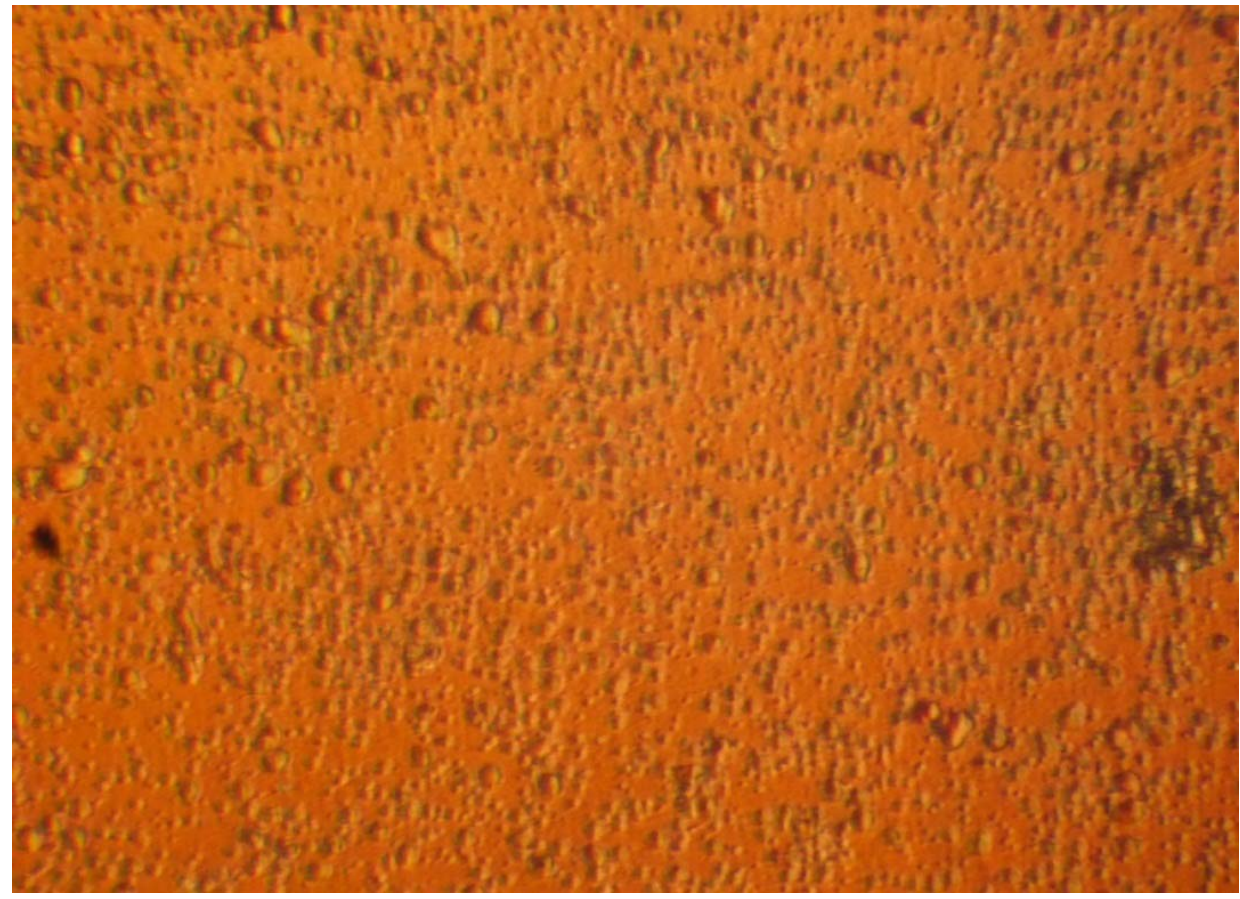

Рис. 3. Розподіл крапель молочного жсиру у пробах молока № 3 від кіз, до раціону яких входив "Еламін»

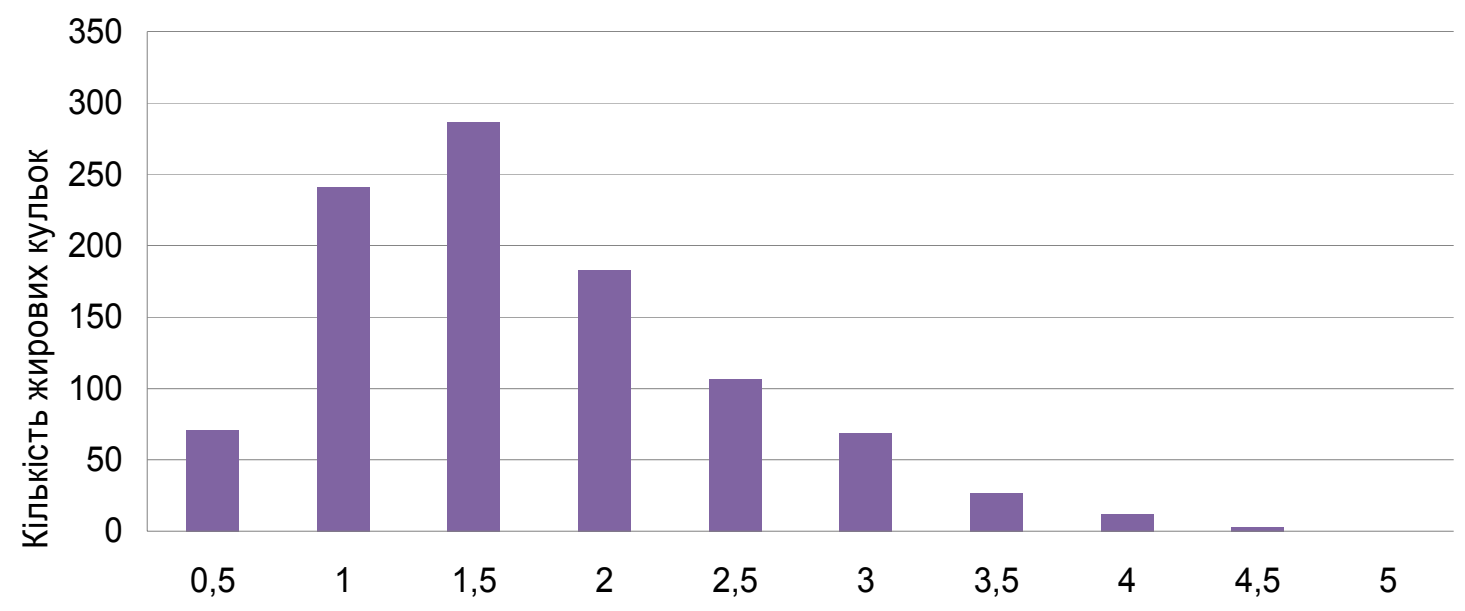

Діаметр жирових кульок, мкм

Рис № 3а. Розподіл розмірів жирових кульок у дослідній пробі молока № 3

\section{Висновки:}

1. Введення в раціон дійних кіз йодовмісних підкормок вирішує проблему усунення йододефіциту в раціонах харчування населення країни.

2. Жирова компонента проб молока, отриманих від тварин, до раціону яких додатково вводили вищевказані добавки «Еламін» та калію йодид, мають більшу дисперсність жирових кульок порівняно з аналогічним показником жи- рової компоненти контрольної проби молока №1 (типового раціону згодовування), що підвищує його засвоюваність організмом людини.

3. Молоко від кіз, до раціону згодовування яких вводили дві вищевказані йодовмісні підкормки, більш технологічне, ніж козине молоко, отримане від кіз звичайного раціону згодовування, поскільки не потребує проведення процесу його гомогенізації. 


\section{БІБЛІОГРАФІЯ}

1. Васильев В. С. Совершенствование методов интерференционной микроскопии для изучения спермы в зависимости от породы, возраста и плодовитости быков : Автореф. дисс. ... канд. биол. наук: 03.00.13 / НИИЖ Лесостепи и Полесья УССР. - Х., 1978. - 24 с.

2. Горбатова К. К. Биохимия молока и молочних продуктов [Текст] / К. К. Горбатова. - М. : Легкая и пищевая промышленность, 1984. - 344 с.

3. Машкин Н. И., Югай Н. А. Влияние кайода на продуктивность и технологические свойства молока коров [Текст] / Н. И. Машкин, Н. А. Югай. Повышение продуктивности крупного рогатого скота // Сб. науч. тр. Харьк. с.- х. ин-та им. В. В. Докучаева. - Т. 293. - Х. : Изд. ХСХИ. - 1983. C. $51-56$.

4. Назаров В. П. Использование концентрата эламина для производства продуктов повышенной биологической ценности [Текст] / В. П. Назаров // Матеріали наук.-практ. конф. «Харчові добавки, інгредієнти, БАДи: їх властивості та використання у виробництві продуктів і напоїв». - K., 2003. - C. 43-44.

5. Патратий А. П. Справочник для работников лабораторий предприятий молочной промышленности [Текст] /А. П. Патратий, В. П. Аристова. М. : Пищевая промышленность, 1980. - 240 с.

6. Рижкова T. М. Залежність виду технологічно- го обробляння від характери-тики його жирових кульок [Текст] // ХДА технології та організації харчування. Прогресивні ресурсозберігаючі технології та їх економічне обгрунтування у підприємствах харчування, економічні проблеми торгівлі. - Х., 2001. - Ч. 1. - С. 212- 219.

7. Рижкова T. М. Вибір оптимальних режимів пастеризації козиного молока для сироваріння [Текст] / Т. М. Рижкова // Молочна промисловість. - 2008. - № 5(48). - С. 56-58.

8. Скороченко T. А. Технологія незбираних молочних продуктів [Текст] / Т. А. Скороченко, Г. Є. Поліщук, О. В. Грек, О. В. Кочубей : навчальний посібник. - Вінниця : Нова книга, 2005. $264 \mathrm{c}$.

9. Цибульская C. А. Овечье молоко [Текст] / С. А. Цибульская // Молочное дело. - 2005. № 7. - C. 32.

10. Andersson M. Current global iodine status and progress over the last decade towards the elimination of iodine deficiency [Text] / M. Andersson, B. Takkouche, I. Egli et al. // Bull. World Health Organ. - 2005. - Vol. 83. - P. 518-525.

11. Delange F. World status of monitoring iodine deficiency disorders control programs [Text] / F. Delange, H. Burgi, Z. P. Chen, J. T. Dunn // Thyroid. - 2002. - Vol. 12. - P. 915-924. 